\title{
Calorific Value and Chemical Properties in Juvenile and Mature Wood of Thermally-Modified Eucalyptus Grandis
}

\section{Kalorijska vrijednost i kemijska svojstva toplinski modificiranoga juvenilnog i zrelog drva eukaliptusa (Eucalyptus grandis)}

\author{
Original scientific paper • Izvorni znanstveni rad \\ Received-prispjelo: 30. 3. 2015. \\ Accepted-prihvaćeno: 5. 5. 2016. \\ UDK: $630 * 812.144 ; 630 * 813.4 ; 674.031 .883 .23$ \\ doi:10.5552/drind.2016.1522
}

\begin{abstract}
During thermal modification, timber is exposed to temperatures approaching $200{ }^{\circ} \mathrm{C}$ for several hours and wood properties change. This study was aimed at evaluating the calorific value and chemical properties of juvenile and mature wood of thermally modified Eucalyptus grandis. Boards were taken from 30-year-old E. grandis trees and thermally modified at $180^{\circ} \mathrm{C}$. Samples of the untreated and thermally modified wood were transformed into chips and then processed into sawdust for the energy and chemical characterization of juvenile and mature wood. The results show that the thermal modification causes: (1) significant increases of $3.7 \%$ and $6.8 \%$, respectively, in the net calorific value of juvenile and mature wood; (2) significant increases of $24.8 \%$ and $47.6 \%$, respectively, in the extractive content of juvenile and mature wood; (3) significant decreases of $4.2 \%$ and $8.3 \%$ in the respective holocellulose content; and (4) significant decreases in the galactose, xylose and glucose contents. It was demonstrated that the influence of thermal treatment was lower in juvenile wood than in mature wood.
\end{abstract}

Key words: biomass, energy, chemical properties, Eucalypts, thermally-modified wood

SAŽETAK - Tijekom postupaka toplinske modifikacije drvo se nekoliko sati izlaže temperaturama do $200{ }^{\circ} \mathrm{C}$, zbog čega se mijenjaju njegova svojstva. Cilj ove studije bio je vrednovati kalorijsku vrijednost i kemijska svojstva toplinski modificiranoga juvenilnog i zrelog drva eukaliptusa (Eucalyptus grandis). Piljenice su izrađene od tridesetogodišnjih stabala eukaliptusa i toplinski modificirane pri $180{ }^{\circ} \mathrm{C}$. Za istraživanje energijskih i kemijskih svojstava juvenilnoga i zrelog drva uzorci nemodificiranoga i toplinski modificiranog drva prerađeni su u iverje, a zatim u piljevinu. Rezultati su pokazali da toplinska modifikacija uzrokuje (1) značajno povećanje neto kalorijske vrijednosti juvenilnoga drva od 3,7\% i 6,8\% zrelog drva; (2) značajno povećanje ekstraktivnih tvari od $24,8 \%$ u

\footnotetext{
Authors are assistant, professor and professor at Department of Forest Science, Faculty of Agricultural Sciences, UNESP, Botucatu-SP, Brazil. ${ }^{2}$ Authors are professor, assistant and professor at Department of Physics and Biophysics, Biosciences Institute, UNESP, Botucatu-SP, Brazil.

Autori su asistent, profesor i profesor Odjela za šumarske znanosti, Fakultet poljoprivrednih znanosti, UNESP, Botucatu-SP, Brazil. ${ }^{2}$ Autori su profesor, asistent i profesor Odjela za fiziku i biofiziku, Institut bioznanosti, UNESP, Botucatu-SP, Brazil.
} 
juvenilnom drvu i 47,6\% u zrelom drvu; (3) značajno smanjenje sadržaja holoceluloze od 4,2\% u juvenilnom drvu i 8,3\% u zrelom drvu te (4) značajno smanjenje sadržaja galaktoze, ksiloze i glukoze. Dokazano je da je utjecaj toplinske modifikacije na energijska i kemijska svojstva juvenilnoga drva manji nego na svojstva zrelog drva.

Ključne riječi: biomasa, energija, kemijska svojstva, eukaliptus, toplinski modificirano drvo

\section{INTRODUCTION}

\section{UVOD}

During thermal modification, timber is exposed to temperatures approaching $200{ }^{\circ} \mathrm{C}$ for several hours. Several heat treatments are used commercially in Europe. They differ in the temperature applied, the use of nitrogen or steam or oils as an inert fluid, and their application to wet or dry wood (Brito et al., 2008; Calonego et al., 2010, 2012; Esteves et al., 2007; Wikberg and Maunu, 2004).

Studies showed an improvement of equilibrium moisture content and dimensional stability of $61.0 \%$ and $90.0 \%$ in Eucalyptus globulus wood after thermal modification at $190-210{ }^{\circ} \mathrm{C}$ (Esteves et al., 2007), and reductions of $21.5 \%$ and $23.2 \%$ in equilibrium moisture content and volumetric swelling in E. grandis wood when thermally-modified at $180{ }^{\circ} \mathrm{C}$ (Calonego et al., 2012). The same wood showed significant reductions of $15.7 \%$ in the weight loss after exposure to Pycnoporus sanguineus fungi when thermally-modified at $180^{\circ} \mathrm{C}$ (Calonego et al., 2010).

When the thermal treatment temperature is increased from $180{ }^{\circ} \mathrm{C}$ to $220{ }^{\circ} \mathrm{C}$, an increase occurs in the number of specimens of E. grandis with fragile failures of $10.5 \%$ to $100.0 \%$ in compression to parallel to grain, and of $15.8 \%$ to $100.0 \%$ in static bending (Calonego et al., 2012). Temperatures greater than 180 ${ }^{\circ} \mathrm{C}$ caused internal cracks in wood of thermally-modified E. grandis (Calonego and Severo, 2010). The thermal treatment of Eucalyptus saligna at $180{ }^{\circ} \mathrm{C}$ caused a decrease of up to $53.2 \%, 62.8 \%, 33.8 \%$, and $35.1 \%$ in the arabinose, galactose, mannose, and xylose contents, respectively, whereas there was a proportional increase of up to $32.5 \%$ in the lignin content of wood (Brito et al., 2008).

Untreated Pinus pinaster wood and thermally modified wood at $260{ }^{\circ} \mathrm{C}$ for $0.5 \mathrm{~h}, 1.0 \mathrm{~h}, 2.0 \mathrm{~h}$ and 4.0 h showed lignin contents of $28 \%, 41 \%, 51 \%, 54 \%$ and $84 \%$, respectively. The respective gross calorific values were 17932.1, 21076.4, 22164.9, 22181.7 and $25845.1 \mathrm{~kJ} / \mathrm{kg}$ (Bourgois and Guyonnet, 1988).

Felfti et al. (2005) studied briquette of thermally modified wood between $220{ }^{\circ} \mathrm{C}$ and $270{ }^{\circ} \mathrm{C}$ during 0.5 to $1.5 \mathrm{~h}$ and concluded that the increase in the temperature and time of the thermal treatment caused degradation of hemicelluloses and improved the calorific value. The gross calorific value was $20020.0 \mathrm{~kJ} / \mathrm{kg}$ for untreated wood and $21065.1 \mathrm{~kJ} / \mathrm{kg}$ and $21209.1 \mathrm{~kJ} / \mathrm{kg}$, respectively, for thermally modified wood at $220^{\circ} \mathrm{C}$ for $1.5 \mathrm{~h}$ and $250{ }^{\circ} \mathrm{C}$ for $0.5 \mathrm{~h}$.

However, the wood is a heterogeneous material and its chemical and physical variations occur due to several factors, e.g. tree species, silviculture, and espe- cially the wood anatomy. Juvenile wood can be defined as being close to the pith and technologically, it differs from mature wood on account of several properties such as: fiber length, density, stability of wood and chemical properties (Bao et al., 2001; Calonego et al., 2005a, 2014; Severo et al., 2012; Zobel and Van Buijtenen 1989).

Moreover, fine residues (wood shavings, sawdust and powder) of wood manufacturing and processing industries have a great potential for generating energy by combustion. According to Quirino et al. (2004), the gross calorific value of two hundred fifty-eight species of wood varies from 16039.6 to $22290.5 \mathrm{~kJ} / \mathrm{kg}$. Zanuncio et al. (2013) concluded that the gross calorific value of Eucalyptus urophylla wood varies between 19770.1 and $20017.1 \mathrm{~kJ} / \mathrm{kg}$. Calonego et al. (2005b) showed that the gross calorific value of E. grandis wood was $19897.8 \mathrm{~kJ} / \mathrm{kg}$.

Since there is no information about the effects of thermal treatment on calorific value of $E$. grandis wood, the aim of this study was to evaluate the calorific value and chemical properties of juvenile and mature wood of this species after thermal modification.

\section{MATERIALS AND METHODS} 2. MATERIJAL I METODE

This study utilized wood from 30-year-old $E$. grandis trees from the Forestry Institute of São Paulo located in Manduri, São Paulo, Brazil. Four trees were felled and sectioned into $2.9 \mathrm{~m} \operatorname{logs}$. The first log from each tree with diameters between $30 \mathrm{~cm}$ and $35 \mathrm{~cm}$ (measured at half height) were cut into flat saw boards. The boards that contained the pith were cut into $28-\mathrm{mm}$ thick pieces. Subsequently, all the boards were dried up to $10.0 \%$ moisture content in a dry kiln.

\subsection{Thermal treatments of boards}

\subsection{Toplinska obrada piljenica}

Four dried boards were planed to 24-mm thickness and cut into smaller pieces measuring $0.60 \mathrm{~m}$ in length. Regions with cracks and knots were discarded. One of these smaller pieces was kept in its original condition (untreated wood), and the other pieces were reserved for the thermal treatment (thermally modified wood).

The material was placed in an electric oven with a programmable controller and thermally modified in the Laboratory of Wood Drying and Preservation of UNESP, Botucatu, SP, in Brazil. The treatment started at an initial temperature of 100 over a period of $14 \mathrm{~h}$ and then was increased $\left(1.34^{\circ} \mathrm{C} /\right.$ minutes $)$ up to $180{ }^{\circ} \mathrm{C}$ and maintained over a period of $2.5 \mathrm{~h}$ according to the application of the patent developed by Severo and 
Calonego (2011). After the end of the thermal treatment, wood pieces were allowed to cool naturally until they reached $30^{\circ} \mathrm{C}$.

Subsequently, samples of the untreated and thermally modified woods were transformed into chips and then processed into sawdust in a slicer type Willey with 20 mesh sieve size $(0.85 \mathrm{~mm})$ for the energy and chemical characterization of juvenile and mature wood. The juvenile and mature wood regions were defined according to Oliveira et al. (1997). The anatomical characterization of the wood used in this study showed that the juvenile wood is confined up to $80 \mathrm{~mm}$ from the pith.

\subsection{Calorific value of wood}

\subsection{Kalorijska vrijednost drva}

The untreated and thermally modified wood sawdust were transformed into pellets and placed in an oven at $103 \pm 2{ }^{\circ} \mathrm{C}$, and maintained in this condition until they reached $0 \%$ moisture content.

The pellet was placed in a calorimeter PARR 1201 in the Laboratory of Applied Physics in the Department of Physics and Biophysics, IB - UNESP, Botucatu, SP, in Brazil. The gross calorific value was determined by bomb calorimeter method according to the standards presented in ABNT NBR-8633 (1984). After the combustion, the Equation 1 was used for determining the gross calorific value of the pellets.

$$
G C V=\frac{\left(K \cdot W_{\mathrm{W}}\right)}{W_{\mathrm{P}}} \cdot \Delta t
$$

Where:

$G C V$ - gross calorific value, $\mathrm{kcal} / \mathrm{kg}$;

$W_{\mathrm{W}}$ - weight of water used in the calorimeter, $2.5 \mathrm{~kg}$;

$W_{\mathrm{P}}$ - oven-dry weight of pellet, $\mathrm{kg}$;

$\Delta t$ - temperature gradient before and after combustion, ${ }^{\circ} \mathrm{C}$; $K$ - calorimeter constant, 489.

The net calorific value was determined by gross calorific value and equilibrium moisture content of the wood according to the Equation 2 presented in Zanuncio et al. (2013).

$$
N C V=G C V-(0.0114 \cdot E M C \cdot G C V)
$$

Where:

$N C V$ - net calorific value, $\mathrm{kcal} / \mathrm{kg}$;

$G C V$ - gross calorific value, $\mathrm{kcal} / \mathrm{kg}$;

$E M C$ - equilibrium moisture content, \%.

Subsequently, the gross and net calorific values determined in $\mathrm{kcal} / \mathrm{kg}$ were mathematically transformed into $\mathrm{kJ} / \mathrm{kg}$.

\subsection{Chemical properties of wood}

\subsection{Kemijska svojstva drva}

The material used for chemical analysis was classified between 40 and 60 mesh $(0.42$ and $0.25 \mathrm{~mm})$. The extractives content was determined by extraction sequences with ethanol/toluene $1 / 2(\mathrm{v} / \mathrm{v})$, ethanol and hot water (TAPPI T $264 \mathrm{~cm}-97,1999)$. The acid-insoluble Klason lignin (TAPPI T 222 om-98, 1999), and holocellulose contents [holocellulose $=100-(\%$ Lignin $+\%$ Extractives Totals)] were determined in extractive-free wood.
The arabinose, galactose, xylose, mannose and glucose were analysed by High-Performance AnionExchange Chromatography with Pulsed Amperometric Detection (HPAE -PAD) in the filtrate obtained of the acid-insoluble Klason lignin. The analysis was carried out by using a chromatograph Thermo-Dionex, ICS5000 with Pulsed Amperometric Detection, CarboPac PA 1 column and $\mathrm{NaOH} 0,5 \mathrm{M}$ as eluent at a flow rate of $1 \mathrm{~mL} / \mathrm{min}$ (Sullivan, 1994).

For the evaluation of calorific value and chemical properties, a Kolmogorov-Smirnov's normality test was performed at $5 \%$ significance. All variables had normal distribution. Subsequently, a parametric test (two-way ANOVA) was performed at $5 \%$ significance taking into account the type of wood and the thermal treatment for the comparison of means of calorific value, extractive, lignin, holocellulose and sugar contents of wood. The Jandel SigmaStat version 2.0 was used for statistical analysis.

\section{RESULTS AND DISCUSSION} 3. REZULTATI I RASPRAVA

\subsection{Calorific value of thermally modified wood}

3.1. Kalorijska vrijednost toplinski modificiranog drva

The gross calorific values of juvenile and mature wood from untreated E. grandis were 19998.3 and $19355.6 \mathrm{~kJ} / \mathrm{kg}$ (Table 1). These results are similar to those cited by Calonego et al. (2005b), Zanuncio et al. (2013), and Quirino et al. (2004).

Table 1 shows that the gross calorific value of $E$. grandis wood has not been significantly changed by thermal modification at $180{ }^{\circ} \mathrm{C}$, although the respective treatment promoted a decrease of up to $3.2 \%$ in terms of physical property studied. Similar results were showed by Felfti et al. (2005), who concluded that the minimum condition that promotes significant improvements in a wood calorific value was $250{ }^{\circ} \mathrm{C}$.

Juvenile wood of untreated and thermally modified $E$. grandis wood, at air conditions $\left(20{ }^{\circ} \mathrm{C}\right.$ and $74 \%$ $\mathrm{RH})$, presents equilibrium moisture content of $10.9 \%$ and $9.1 \%$, respectively. In mature wood, the respective moisture contents were $11.1 \%$ and $8.4 \%$.

Table 1 shows that the thermal treatment at 180 ${ }^{\circ} \mathrm{C}$ promoted significant reductions of $16.5 \%$ and 24.3 $\%$ in the equilibrium moisture content of juvenile and mature woods. The influence of thermal treatment was lower on juvenile wood than on mature wood both in terms of calorific value and moisture content. Similar behavior was reported by Severo et al. (2012) and Calonego et al. (2014), who studied the changes of some properties of E. grandis and P. elliotti var. elliottii woods during thermal modification. According to the authors, the juvenile wood has an adverse effect on modification.

Due to smaller equilibrium moisture content in the thermally-modified wood of E. Grandis, more useful energy is generated through combustion, since the moisture present in certain materials uses part of the gross energy released. Thus the net calorific value is the better way to quantify the energy potential of wood. Table 1 
Table 1 Equilibrium moisture content and calorific value of juvenile and mature wood from thermally modified E. grandis Tablica 1. Ravnotežni sadržaj vode i kalorijska vrijednost toplinski modificiranoga juvenilnog i zrelog drva eukaliptusa

\begin{tabular}{|c|c|c|c|c|c|c|c|c|c|c|c|}
\hline \multirow[t]{2}{*}{$\begin{array}{l}\text { Wood } \\
\text { Drvo }\end{array}$} & \multicolumn{5}{|c|}{$\begin{array}{c}\text { E.M.C. at air }-20^{\circ} \mathbf{C} \text { and } \\
\mathbf{7 4} \% \mathbf{R H} \\
\text { EMC pri temperaturi zraka } \\
20^{\circ} \mathrm{C} \text { i vlažnosti od } 74 \% \\
\% \\
\end{array}$} & \multicolumn{3}{|c|}{$\begin{array}{c}\text { Gross calorific value } \\
\text { Bruto kalorijska vrijednost } \mathrm{kJ} / \mathrm{kg}\end{array}$} & \multicolumn{3}{|c|}{$\begin{array}{c}\text { Net calorific value } \\
\text { Neto kalorijska vrijednost } \\
\mathrm{kJ} / \mathrm{kg}\end{array}$} \\
\hline & $\mathrm{N}$ & U & $\mathrm{N}$ & $\mathrm{TM}$ & $\begin{array}{l}\text { Red. or } \\
\text { (Inc.) \% }\end{array}$ & U & TM & (Inc.) $\%$ & U & $\mathrm{TM}$ & (Inc.) $\%$ \\
\hline $\begin{array}{l}\text { Juvenile } \\
\text { juvenilno }\end{array}$ & 4 & \begin{tabular}{|l|}
10.9 \\
{$[0.3]$} \\
\end{tabular} & 4 & $\begin{array}{c}9.1 \\
{[0.4]}\end{array}$ & $16.5^{*}$ & $\begin{array}{l}19998.3 \\
{[802.2]}\end{array}$ & $\begin{array}{c}20278.8 \\
{[803.5]} \\
\end{array}$ & $(1.4)^{\mathrm{NS}}$ & $\begin{array}{l}17520.5 \\
{[753.6]}\end{array}$ & $\begin{array}{l}18169.0 \\
{[720.6]}\end{array}$ & $(3.7)^{*}$ \\
\hline $\begin{array}{l}\text { Mature } \\
\text { zrelo }\end{array}$ & 4 & $\begin{array}{l}11.1 \\
{[0.5]}\end{array}$ & 4 & $\begin{array}{c}8.4 \\
{[0.4]}\end{array}$ & $24.3^{*}$ & $\begin{array}{l}19355.6 \\
{[892.2]}\end{array}$ & $\begin{array}{l}19975.2 \\
{[732.3]}\end{array}$ & $(3.2)^{\mathrm{NS}}$ & $\begin{array}{l}16911.3 \\
{[772.9]}\end{array}$ & $\begin{array}{l}18057.3 \\
{[686.6]}\end{array}$ & $(6.8)^{*}$ \\
\hline $\begin{array}{l}\text { Red. or } \\
\text { (Inc.) \% }\end{array}$ & & $\begin{array}{l}\text { (1.8) } \\
\text { Ns }\end{array}$ & & $\begin{array}{c}7.7 \\
*\end{array}$ & & $3.2^{\mathrm{NS}}$ & $1.5^{\mathrm{NS}}$ & & $3.5^{\mathrm{NS}}$ & $0.6^{\mathrm{NS}}$ & \\
\hline
\end{tabular}

E.M.C. - Equilibrium moisture content / ravnotežni sadržaj vode, Red. - Reduction / smanjenje, Inc. - Increase / povećanje, N - Repeated number of samples / broj uzoraka, U - Untreated wood / netretirano drvo, TM - Thermally-modified wood / toplinski modificirano drvo, []standard deviation / standardna devijacija, * - Significant difference by $\mathrm{F}$ test at $95 \%$ probability / signifikantna razlika prema F-testu $i$ vjerojatnosti $95 \%,{ }^{\mathrm{NS}}$ - Non-significant difference / nesignifikantna razlika.

shows that the thermal treatment at $180{ }^{\circ} \mathrm{C}$ promoted significant increase of $3.7 \%$ and $6.8 \%$, respectively, in the net calorific value of juvenile and mature woods.

\subsection{Chemical properties of thermally modified wood}

3.2. Kemijska svojstva toplinski modificiranog drva

The lignin, holocellulose, and extractive contents of juvenile wood from untreated $E$. grandis were 26.12 $\%, 73.69 \%$, and $2.06 \%$, respectively. In mature wood, these components were $28.27 \%, 72.77 \%$, and $2.46 \%$. These results are presented in Table 2, and are similar to those cited by Bao et al. (2001), Brito et al. (2008), and Zobel and Van Buijtenen (1989).

Table 3 verifies that the galactose, xylose, and glucose contents in juvenile wood from untreated $E$. grandis were $0.32 \%, 16.35 \%$, and $57.02 \%$, respectively. In mature wood from untreated $E$. grandis, the respective contents were $0.55 \%, 14.18 \%$, and $58.02 \%$. These results are similar to those reported by Brito et al. (2008) for E. grandis wood.

The results of qualitative determination of sugars are also presented in Figure 1 and 2. The peak of

Table 2 Chemical compounds of juvenile and mature woods from thermally modified $E$. grandis

Tablica 2. Kemijska svojstva toplinski modificiranoga juvenilnog i zrelog drva eukaliptusa

\begin{tabular}{|c|c|c|c|c|c|c|c|c|c|c|c|}
\hline \multirow[t]{2}{*}{$\begin{array}{l}\text { Wood } \\
\text { Drvo }\end{array}$} & \multicolumn{5}{|c|}{$\begin{array}{c}\text { Extractives content } \\
\text { Sadržaj ekstrativnih tvari } \\
\%\end{array}$} & \multicolumn{3}{|c|}{$\begin{array}{c}\text { Insoluble lignin content } \\
\text { Sadržaj netopljivog lignina } \\
\%\end{array}$} & \multicolumn{3}{|c|}{$\begin{array}{c}\text { Holoceluloses content } \\
\text { Sadržaj holoceluloze } \\
\%\end{array}$} \\
\hline & $\mathrm{N}$ & $\mathrm{U}$ & $\mathrm{N}$ & TM & (Inc.) $\%$ & $\mathrm{U}$ & TM & (Inc.) $\%$ & $\mathrm{U}$ & TM & Red. \% \\
\hline $\begin{array}{l}\text { Juvenile } \\
\text { juvenilno }\end{array}$ & 4 & $\begin{array}{c}2.06 \\
{[0.21]}\end{array}$ & 4 & $\begin{array}{c}2.57 \\
{[0.59]}\end{array}$ & $(24.8)^{*}$ & $\begin{array}{l}26.12 \\
{[0.69]}\end{array}$ & $\begin{array}{l}26.12 \\
{[1.15]}\end{array}$ & $0.0^{\mathrm{NS}}$ & $\begin{array}{l}73.69 \\
{[0.79]}\end{array}$ & $\begin{array}{l}70.61 \\
{[1.52]}\end{array}$ & $4.2 *$ \\
\hline $\begin{array}{l}\text { Mature } \\
\text { zrelo }\end{array}$ & 4 & $\begin{array}{c}2.46 \\
{[0.48]}\end{array}$ & 4 & $\begin{array}{c}3.63 \\
{[0.74]}\end{array}$ & $(47.6)^{*}$ & $\begin{array}{l}28.27 \\
{[1.12]}\end{array}$ & $\begin{array}{l}30.41 \\
{[1.34]}\end{array}$ & $(7.6)^{\mathrm{NS}}$ & $\begin{array}{l}72.77 \\
{[0.71]}\end{array}$ & $\begin{array}{l}66.71 \\
{[1.43]}\end{array}$ & $8.3 *$ \\
\hline Red. or (Inc.) \% & & $(19.4)^{*}$ & & $\begin{array}{c}(41.3) \\
*\end{array}$ & & $\begin{array}{c}(8.2) \\
*\end{array}$ & $(16.4)^{*}$ & & $1.3^{\mathrm{NS}}$ & $5.5^{*}$ & \\
\hline
\end{tabular}

Red. - Reduction / smanjenje, Inc. - Increase / povećanje, N - Repeated number of samples / broj uzoraka, U - Untreated wood / netretirano drvo, TM - Thermally-modified wood / toplinski modificirano drvo, []- standard deviation / standardna devijacija, * - Significant difference by F test at $95 \%$ probability / signifikantna razlika prema F-testu i vjerojatnosti $95 \%$, Ns - Non-significant difference / nesignifikantna razlika.

Table 3 Sugar content of juvenile and mature wood from thermally modified E. grandis

Tablica 3. Sadržaj šećera toplinski modificiranoga juvenilnog i zrelog drva eukaliptusa

\begin{tabular}{|l|c|c|c|c|c|c|c|c|c|c|c|}
\hline \multirow{2}{*}{$\begin{array}{c}\text { Wood } \\
\text { Drvo }\end{array}$} & \multicolumn{4}{c|}{$\begin{array}{c}\text { Galactose content } \\
\text { Sadržaj galaktoze } \\
\text { \% }\end{array}$} & \multicolumn{3}{|c|}{$\begin{array}{c}\text { Xylose content } \\
\text { Sadržaj ksiloze } \\
\%\end{array}$} & \multicolumn{3}{c|}{$\begin{array}{c}\text { Glucose content } \\
\text { Sadržaj glukoze } \\
\%\end{array}$} \\
\cline { 2 - 13 } & $\mathrm{N}$ & $\mathrm{U}$ & $\mathrm{N}$ & $\mathrm{TM}$ & Red. \% & $\mathrm{U}$ & $\mathrm{TM}$ & Red. \% & $\mathrm{U}$ & $\mathrm{TM}$ & (Inc.) \% \\
\hline $\begin{array}{l}\text { Juvenile } \\
\text { juvenilno }\end{array}$ & 4 & $\begin{array}{c}0.32 \\
{[0.10]}\end{array}$ & 4 & $\begin{array}{c}0.33 \\
{[0.07]}\end{array}$ & $(3.1)^{\mathrm{NS}}$ & $\begin{array}{c}16.35 \\
{[0.71]}\end{array}$ & $\begin{array}{c}15.49 \\
{[0.51]}\end{array}$ & $5.3 *$ & $\begin{array}{c}57.02 \\
{[1.35]}\end{array}$ & $\begin{array}{c}54.80 \\
{[1.15]}\end{array}$ & $3.9^{*}$ \\
\hline $\begin{array}{l}\text { Mature } \\
\text { zrelo }\end{array}$ & 4 & $\begin{array}{c}0.55 \\
{[0.06]}\end{array}$ & 4 & $\begin{array}{c}0.34 \\
{[0.11]}\end{array}$ & $38.2^{*}$ & $\begin{array}{c}14.18 \\
{[0.62]}\end{array}$ & $\begin{array}{c}12.21 \\
{[1.62]}\end{array}$ & $13.9 *$ & $\begin{array}{c}58.02 \\
{[0.79]}\end{array}$ & $\begin{array}{c}54.16 \\
{[1.11]}\end{array}$ & $6.7^{*}$ \\
\hline Red. or (Inc.) \% & & $(71.9)^{*}$ & & $\begin{array}{c}(3.0) \\
\mathrm{NS}\end{array}$ & & $13.3 *$ & $21.2 *$ & & $(1.8)^{\mathrm{NS}}$ & $1.2^{\mathrm{NS}}$ & \\
\hline
\end{tabular}

Red. - Reduction / smanjenje, Inc. - Increase / povećanje, N - Repeated number of samples / broj uzoraka, U - Untreated wood / netretirano drvo, TM - Thermally-modified wood / toplinski modificirano drvo, []- standard deviation / standardna devijacija, * - Significant difference by $\mathrm{F}$ test at $95 \%$ probability / signifikantna razlika prema F-testu i vjerojatnosti $95 \%$, ${ }^{\mathrm{NS}}$ - Non-significant difference / nesignifikantna razlika. 
...... Calonego, Durgante Sever, Sansígolo, Rezende, Bruder, Costa: Calorific Value and...

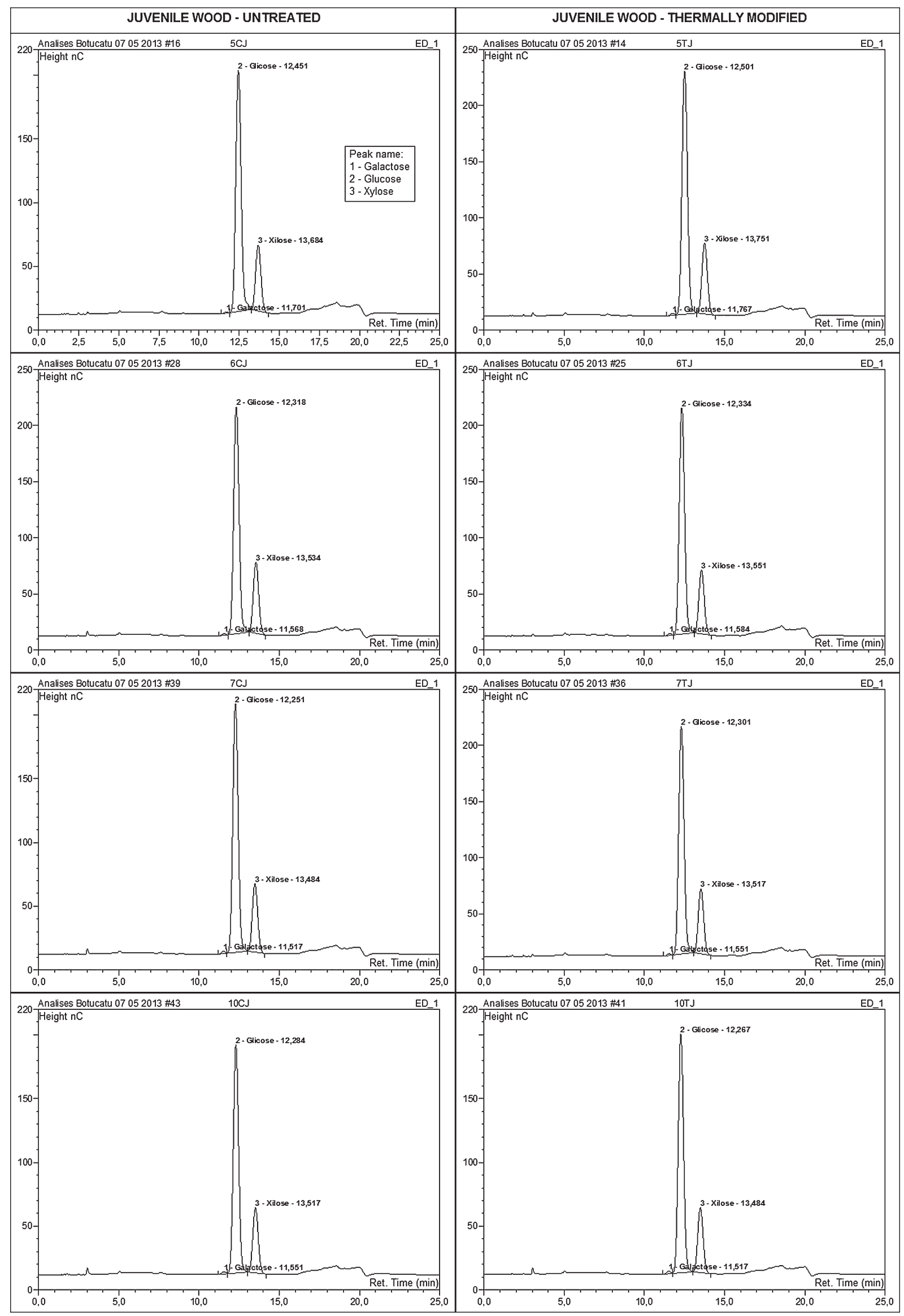

Figure 1 Chromatograms of extracts of juvenile wood from thermally modified E. grandis

Slika 1. Kromatogrami ekstraktivnih tvari u toplinski modificiranome juvenilnom drvu eukaliptusa 
Calonego, Durgante Sever, Sansígolo, Rezende, Bruder, Costa: Calorific Value and... ......

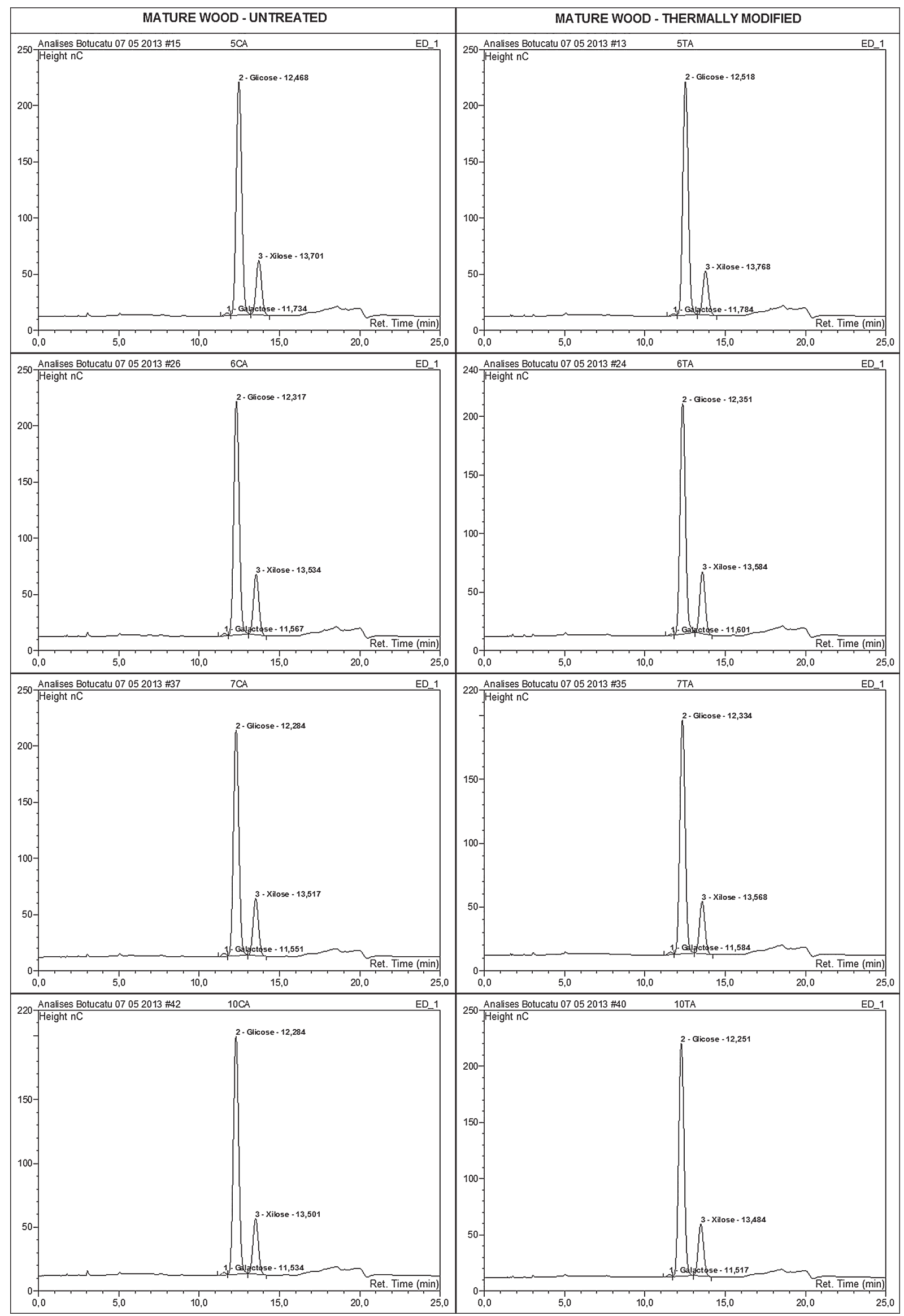

Figure 2 Chromatograms of extracts of mature wood from thermally modified $E$. grandis

Slika 2. Kromatogrami ekstraktivnih tvari u toplinski modificiranome zrelom drvu eukaliptusa 
galactose, xylose and glucose by the chromatograms of extracts of untreated and thermally modified wood can be seen.

The effect of thermal treatment on the chemical properties of E. grandis wood is shown in detail in Table 2 and 3 .

The current study demonstrates that the juvenile and mature wood from thermally modified $E$. grandis presented $2.57 \%$ and $3.63 \%$ in the respective extractive contents when compared with the values found for untreated wood, which were $2.06 \%$ and $2.46 \%$. Mature wood, when thermally modified, showed a proportional increase of $7.6 \%$ in the insoluble lignin content, whereas juvenile wood showed no change by thermal treatment. The mature wood, when thermally modified, showed greater significant reduction $(8.3 \%)$ in holocellulose content than juvenile wood $(4.2 \%)$.

The thermal treatment of mature wood of $E$. grandis at $180{ }^{\circ} \mathrm{C}$ caused a decrease of $38.2 \%, 13.9 \%$, and $6.7 \%$ in the galactose, xylose, and glucose contents. The influence of thermal treatment in juvenile wood was lower than in mature wood. Similar changes were reported by Bourgois and Guyonnet (1988), Brito et al. (2008), Severo et al. (2012), Bächle et al. (2010) and Wikberg and Maunu (2004), who studied the variations in the chemical properties of other kinds of wood during the thermal modification.

The changes in chemical properties of thermally modified E. grandis wood can explain the increase in the calorific value. Similar behavior was reported by Bourgois and Guyonnet (1988), who concluded that the thermal treatment in Pinus pinaster wood at 260 ${ }^{\circ} \mathrm{C}$ during 0.5 to $4 \mathrm{~h}$ caused an increase between 46.4 $\%$ and $200 \%$ in the lignin contents, and between 17.5 $\%$ and $44.1 \%$ in the gross calorific value. These results are similar to those reported by Felfti et al. (2005) who concluded that the increase in the temperature and the time of the thermal treatment causes degradation of hemicelluloses and increase the calorific value of wood.

\section{CONCLUSIONS}

\section{ZAKLJUČAK}

This study shows that thermal modification of Eucalyptus grandis wood increases its net calorific value up to $6.8 \%$. Regarding chemical properties, significant increase was detected in the extractive content of juvenile and mature wood and reduction in the holoceluloses and sugar contents, when it was submitted to the thermal modification at $180^{\circ} \mathrm{C}$. Finally, the influence of thermal treatment in juvenile wood was lower than in mature wood.

\section{Acknowledgments - Zahvala}

The authors thank the Research Assistance Foundation from São Paulo (FAPESP) and the Coordinator for the Improvement of Higher Level Personnel (CAPES), Brazil, for financial support through grant numbers 05/59074-7 and PNPD-02405/09-1.

\section{REFERENCES}

\section{LITERATURA}

1. Bächle, H.; Zimmer, B.; Windeisen, E.; Wegener, G., 2010: Evaluation of thermally modified beech and spruce wood and their properties by FT-NIR spectroscopy. Wood Sci. Technol., 44: 421-433.

http://dx.doi.org/10.1007/s00226-010-0361-3.

2. Bao, F. C.; Jiang, Z. H.; Jiang, X. M.; Lu, X. X.; Luo, X. Q.; Zhang, S. Y., 2001: Differences in wood properties between juvenile wood and mature wood in 10 species grown in China. Wood Sci. Technol., 35: 363-375. http://dx.doi.org/10.1007/s002260100099.

3. Bourgois, J.; Guyonnet, R., 1988: Characterization and analysis of torrefied wood. Wood Sci. Technol., 22: 143155. http://dx.doi.org/10.1007/BF00355850.

4. Brito, J. O.; Silva, F. G.; Leão, M. M.; Almeida, G., 2008: Chemical composition changes in eucalyptus and pinus woods submitted to heat treatment. Bioresour. Technol., 99: 8545-8548.

http://dx.doi.org/10.1016/j.biortech.2008.03.069.

5. Calonego, F. W.; Severo, E. T. D., 2010: Dimensional change Eucalyptus grandis timber during some levels of retification temperature and time. Energia Agric., 25 (3): 58-67.

6. Calonego, F. W.; Severo, E. T. D.; Assi, P. P., 2005a: Fiber length measurement from the determination of juvenile wood in Eucalyptus citriodora. Sci. For. 68: 113-121.

7. Calonego, F. W.; Severo, E. T. D.; Ballarin, A. W., 2012: Physical and mechanical properties of thermally-modified wood from Eucalyptus grandis. Eur. J. Wood Prod., 70 (4): 453-460. http://dx.doi.org/10.1007/s00107-011-0568-5.

8. Calonego, F. W.; Severo, E. T. D.; Latorraca, J. V. F., 2014: Effect of thermal modification on the physical properties of juvenile and mature woods of Eucalyptus grandis. Floresta Ambient., 21 (1): 108-113. http://dx.doi.org/10.4322/floram.2014.004.

9. Calonego, F. W.; Severo, E. T. D.; Perrechil, M. V. A.; Rezende, M. A.; Latorraca, J. V. F., 2005b: Effect of steaming on the calorific value of Eucalyptus grandis. Floresta Ambient., 12 (1): 30-35.

10. Calonego, F. W.; Severo, E. T. D.; Furtado, E. L., 2010: Decay resistance of thermally-modified Eucalyptus grandis wood at $140{ }^{\circ} \mathrm{C}, 160{ }^{\circ} \mathrm{C}, 180^{\circ} \mathrm{C}, 200{ }^{\circ} \mathrm{C}$ and 220 ${ }^{\circ} \mathrm{C}$. Bioresour. Technol., 101: 9391-9394. http://dx.doi.org/10.1016/j.biortech.2010.06.119.

11. Esteves, B.; Marques, A. V.; Domingos, I.; Pereira, H., 2007: Influence of steam heating on the properties of pine (Pinus pinaster) and eucalypt (Eucalyptus globulus) wood. Wood Sci. Technol., 41 (3): 193-207. http://dx.doi.org/10.1007/s00226-006-0099-0.

12. Felfti, F. F.; Luengo, C. A.; Suárez, J. A.; Beatón, P. A., 2005: Wood briquette torrefaction. Energy Sust. Develop., 9 (3): 19-22. http://dx.doi.org/10.1016/S0973-0826(08)60519-0.

13. Oliveira, J. T. S., 1997: Characterization of eucalyptus wood for building construction. Dr. Sc. diploma thesis. University of São Paulo (USP). Polytechnic School. São Paulo, (1997), $429 \mathrm{p}$.

14. Quirino, W. F.; Vale, A. T.; Andrade, A. P. A.; Abreu, V. L. S.; Azevedo, A. C. S., 2004: Calorific value of wood and wood residues. Biomassa e Energia, 1 (2): 173-182.

15. Severo, E. T. D.; Calonego, F. W., 2011: Thermal modification process for heat radiation to improve the dimensional stability and biological durability of solid wood. INPI Patent no PI0902/38-8A2. Patent Off., Rio de Janeiro, R.J., 17 p. 
16. Severo, E. T. D.; Calonego, F. W.; Sansígolo, C. A., 2012: Physical and chemical changes in juvenile and mature woods of Pinus elliottii var. elliottii by thermal modification. Eur. J. Wood Prod., 70: 741-747. http://dx.doi.org/10.1007/s00107-012-0611-1.

17. Sullivan, J., 1994: Determination of carbohydrates in wood, pulp and process liquor samples using high performance anion-exchange chromatography with pulsed amperometric detection. J. of Chromatography, 671 (1-2): 339-350.

http://dx.doi.org/10.1016/0021-9673(94)80259-9

18. Wikberg, H.; Maunu, S. L., 2004: Characterization of thermally-modified hard- and softwoods by ${ }^{13 \mathrm{C}}$ CPMAS NMR. Carbohydr. Polymer., 58: 461-466. http://dx.doi.org/10.1016/j.carbpol.2004.08.008.

19. Zanuncio, A. J. V.; Monteiro, T. C.; Lima, J. T.; Andrade, H. B.; Carvalho, A. G., 2013: Drying biomass for energy use of Eucalyptus urophylla and Corymbia citriodora logs. Bioresour., 8 (4): 5159-5168. http://dx.doi.org/10.15376/biores.8.4.5159-5168

20. Zobel, B. J.; Van Buijtenen, J. P., 1989: Wood variation: its causes and control. New York: Springer-Verlag. http://dx.doi.org/10.1007/978-3-642-74069-5
21. *** ABNT NBR 8633, 1984: Charcoal: determination of calorific value. Rio de Janeiro: Associação Brasileira de Normas Técnicas.

22. *** TAPPI $264 \mathrm{~cm}-97,1999$ : Preparation of wood for chemical analysis. Atlanta: Technical Association of the Pulp and Paper Industry, 1999.

23. *** TAPPI $222 \mathrm{~cm}-98,1999$ : Acid-Insoluble Lignin in Wood and Pulp. Atlanta: Technical Association of the Pulp and Paper Industry.

\section{Corresponding address:}

Ing. FRED WILLIANS CALONEGO, Ph.D.

Department of Forest Science, Faculty of Agricultural Sciences, UNESP

Fazenda Experimental Lageado - Botucatu, SP

BRAZIL, CEP: 18603-970

e-mail: fwcalonego@ig.com.br 